\title{
Surface Ultrastructure of the Gills of Odontesthes bonariensis (Valenciennes, 1835) (Teleostei: Atheriniformes) from a Temperate Shallow Lake
}

\author{
Estudio Ultraestructural de las Branquias de Odontesthes bonariensis \\ (Valenciennes, 1835) (Teleostei: Atheriniformes) de un Lago Somero Templado
}

\author{
María Florencia Tano de la Hoz ${ }^{*, * *}$; María Victoria Longo**; ${ }^{*}$ Alicia Haydée Escalante ${ }^{*, * *}$ \& Alcira Ofelia Díaz ${ }^{* * *}$
}

TANO DE LA HOZ, M. F.; LONGO, M. V.; ESCALANTE, A. H. \& DÍAZ, A. O. Surface ultrastructure of the gills of odontesthes bonariensis (valenciennes, 1835) (Teleostei: Atheriniformes) from a temperate shallow lake. Int. J. Morphol., 32(4):1341-1346, 2014.

SUMMARY: We studied the gill epithelium of juveniles of Odontesthes bonariensis using scanning electron microscopy with a particular interest in the relationship between cell morphology and the different functional aspects of gills. The specimens used were collected in Laguna de los Padres, Buenos Aires Province, Argentina. The gill filaments or primary lamellae are arranged in two rows along the convex outer face of the gill arch forming the anterior and posterior hemibranchiae. On its concave inner face, each arch supports two rows of gill rakers forming the pharyngeal region wall. The primary lamellae are lined by a stratified epithelium made up of polygonal cells with well-defined outlines and cell membrane microfolds. Several mucous and chloride cells were observed in the primary lamellae. The epithelial cells of the secondary lamellae have ill-defined outlines and few microfolds. Both the arches and gill rakers are covered by a stratified epithelium of polygonal cells, among which mucous cells and taste corpuscles are abundant. The ultrastructural analysis of gills of $O$. bonariensis contributes to the advancement of knowledge of the organ histophysiology and of future histopathological studies.

KEY WORDS: Morphology; SEM; Gills; Fishes; Odontesthes bonariensis.

\section{INTRODUCTION}

The silverside Odontesthes bonariensis (Valenciennes, 1835) (Atheriniformes, Atherinopsidae) is an important commercial species in South America and has been introduced in several water bodies around the world for aquaculture. Due to the quality of its meat and its sports fishing value, it is probably economically the most important freshwater species of the Buenos Aires province. These facts have increased the interest on the study of the morphology, physiology and pathological anatomy of the species.

Of late years, the silverside has been used in several studies of the digestive and neuroendocrine systems (Díaz et al., 2006; Somoza et al., 2008; Vigliano et al., 2011). Nevertheless, previous records on the respiratory system are scarce. The morphology of gills (Vigliano et al., 2006) and the histochemical characteristics of glycoproteins secreted by mucous cells (Díaz et al., 2010) have been described; however, no exhaustive studies on the ultrastructural features of $O$. bonariensis gills using scanning electron microscope (SEM) have been done to date.
In fish, the gills have several vital functions such as gaseous exchange, ionic transport, nitrogenous waste excretion, acid-base regulation and detoxification (Perry, 1997). Due to their external location and their close and continuous contact with water, gills are frequently one of the organs most affected through pathogenic agents and aquatic environment contaminants, being one of the first organs showing significant pathological changes. The modifications of the ultrastructural surface of gills can reflect the fish health and the physiological status (Fernandes \& Perna-Martins, 2002). Hence, the knowledge of the normal structural features of gills contributes to better understand the diverse physiological processes that occur in the organ (Carmona et al., 2004; Monteiro et al., 2010). Moreover, the gills are sensitive indicators of environmental stress, including exposure to harmful compounds present in aquatic ecosystems as a result of human activities (Vigliano et al., 2006).

The objective of this study comprises the analysis of the general morphology and the ultrastructure of gills of the

\footnotetext{
* Consejo Nacional de Investigaciones Científicas y Técnicas (CONICET), Buenos Aires, Argentina.

** Instituto de Investigaciones Marinas y Costeras (IIMyC), FCEyN, CONICET-Universidad Nacional de Mar del Plata, Buenos Aires, Argentina. This research was partly supported by grants from the Universidad Nacional de Mar del Plata (UNMdP) EXA 578 /12.
} 
silverside $O$. bonariensis through scanning electron microscopy. The ultrastructure characterization of gills of the species will provide the morphological basis for the advance of the organ's histophysiological knowledge and for future histopathological studies.

\section{MATERIAL AND METHOD}

The specimens of Odontesthes bonariensis used in this research were obtained from Laguna de los Padres (Province of Buenos Aires, Argentina). Fish were anesthetized with Tricaine (MS-222) before being measured, weighed and sexed. Healthy juvenile specimens of $O$. bonariensis (length $14.5 \pm 2.0$ $\mathrm{cm}$, weight $9.9 \pm 5.0 \mathrm{~g} ; \mathrm{N}=5$ ) were selected and their gill arches immediately removed. The second gill arch (BaII) of each fish was isolated and fixed in a 3\% glutaraldehyde solution buffered with $0.1 \mathrm{M}$ sodium cacodylate and routinely processed for SEM. The dehydration was gradually done; the material was dried with hexamethyldisilazane (HMDS), mounted on aluminum stubs and metalized with gold/palladium. Observations and photographs were done under a SEM JEOL JSM 6460-LV microscope of the Laboratory for Electron Microscopy of the National University of Mar del Plata.

Selection of the BaII representing the other gill-arches of the fish was performed according to previously established methodologies in other researches (Eiras-Stofella et al., 2001; Eiras-Stofella \& Fank-de-Carvalho, 2002).

\section{RESULTS}

General structure. The gill filaments or primary lamellae of Odontesthes bonariensis are arranged in two rows along the gill arch forming the anterior and posterior hemibranchiae, making up the holobranch. The length of the gill filaments varies with the different gill arches and also with their different locations in a given arch. The gill filaments are extremely long in the medial portion of the arch, being shorter in the dorsal and ventral ends (Fig. 1a). Each arch supports two rows of gill rakers that are part of the complex wall of the pharyngeal cavity. The gill rakers are located in the inner concave face of the gill arches, while the holobranchiae are located in the outer convex face, pointing at the opercular cavity (Fig. 1a and b). The gill rakers of the first holobranch are thinner and longer than the gill rakers of consecutive holobranchiae.

Gill Filaments. A variable number of gill lamellae or secondary lamellae irradiates from the dorsal and ventral surface of each filament (Fig. 2a and b). In the distal end of the

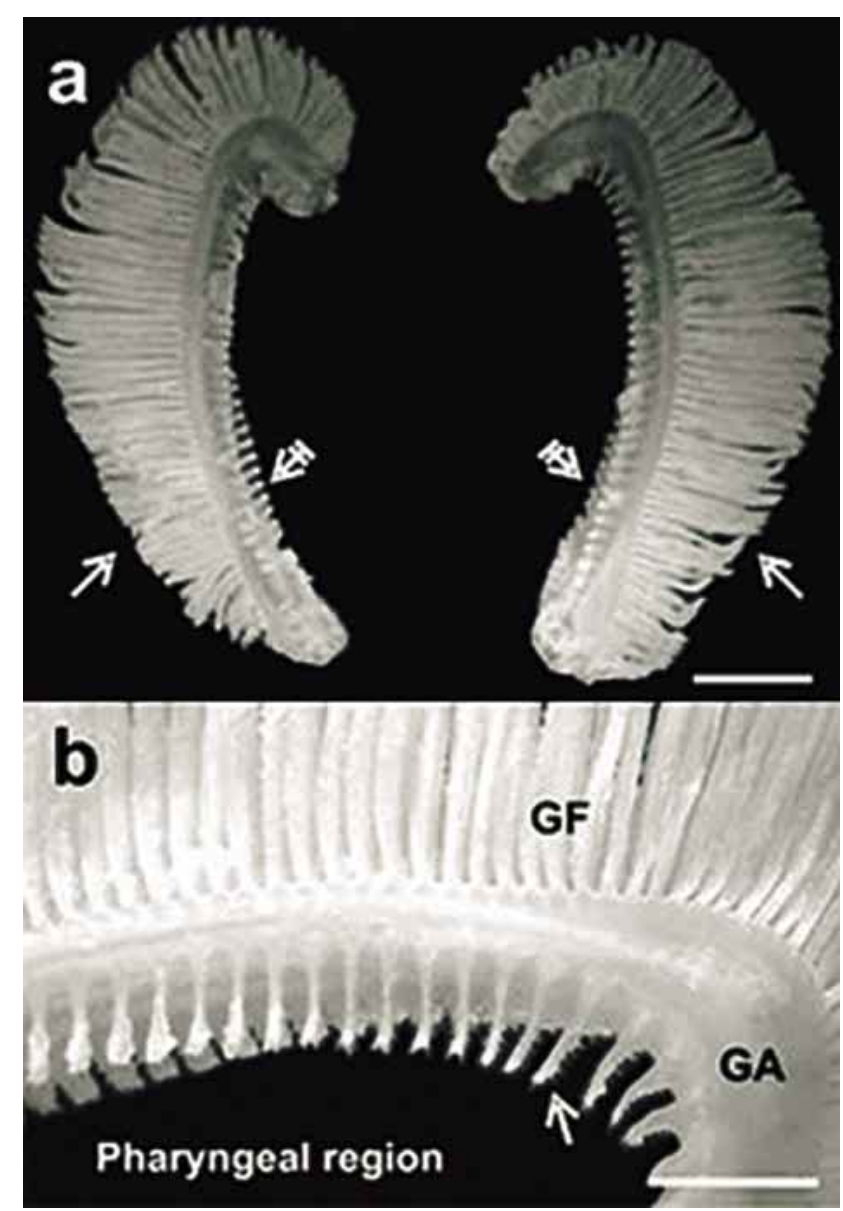

Fig. 1. (a) General aspect of the second gill arch of Odontesthes bonariensis. Note gill rakers (barred arrows) on pharyngeal side and gill filaments (arrows) on opercular side. Scale bar: $5 \mathrm{~mm}$. (b) Photograph of the gill arch (GA) showing the gill filaments (GF) and the gills rakers studded with villiform spines (arrow). Scale bar: $2 \mathrm{~mm}$.

gill filaments, the secondary lamellae are small and triangleshaped, while in the medial and proximal regions they are longer and rectangle-shaped. The gill filaments are covered by a stratified epithelium with fine folds, having at SEM a softly undulated surface appearance. The epithelium is made up of pavement polygonal cells with well-defined contours, and long and concentric microridges frequently interconnected by fine transversal connections called microbridges (Fig. 3a). The microridges tend to be shorter in the transition zone, from the gill filaments to the secondary lamellae. The epithelial cells of the secondary lamellae have weakly defined contours and scarce and short microridges. Mucous cells are present in the primary lamellae and also in the secondary lamellae; the apical surfaces of the cells are seen at SEM completely covered by secretion granules (Fig. 3b). Chloride cells are in the afferent surface of filaments, in the interlamellar surface and around the base of the secondary lamellae. The epithelial pavement cells are interrupted by the chloride cell crypts, which possess 

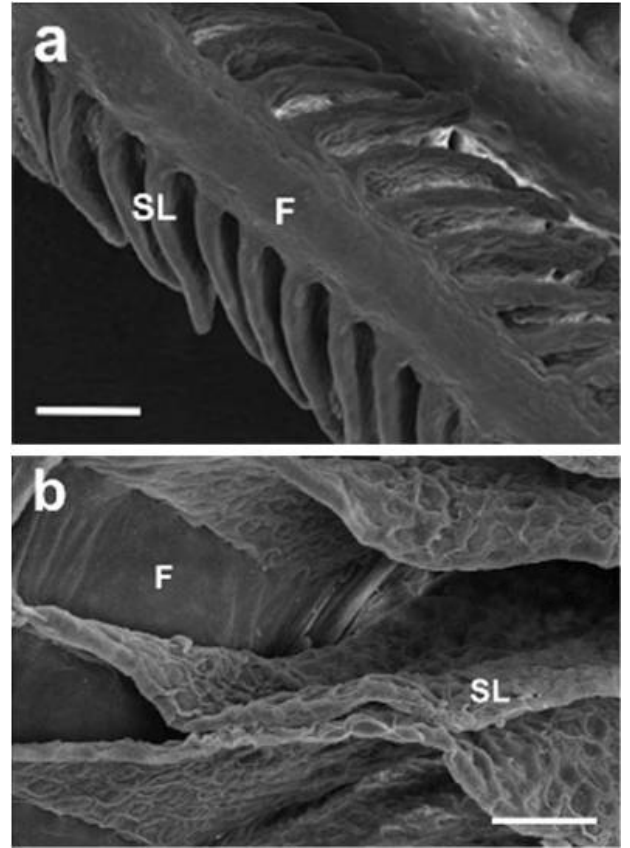

Fig. 2. (a, b) Structure of the filaments $(F)$ and secondary lamellae (SL). Scale bars: (a) $50 \mu \mathrm{m}$. (b) $20 \mu \mathrm{m}$.

similar-length apical projections that extend among the neighboring epithelial cells (Fig. 3c).

Pharyngeal Region. The stratified epithelium covering the gill arches and gill rakers of $O$. bonariensis is characterized by the presence of a large number of irregularly distributed protuberances and invaginations of variable depth (Fig. 4a); it is a mosaic of polygonal epithelial cells of uniform appearance and dimensions. The epithelial surface is studded with villiform spines,

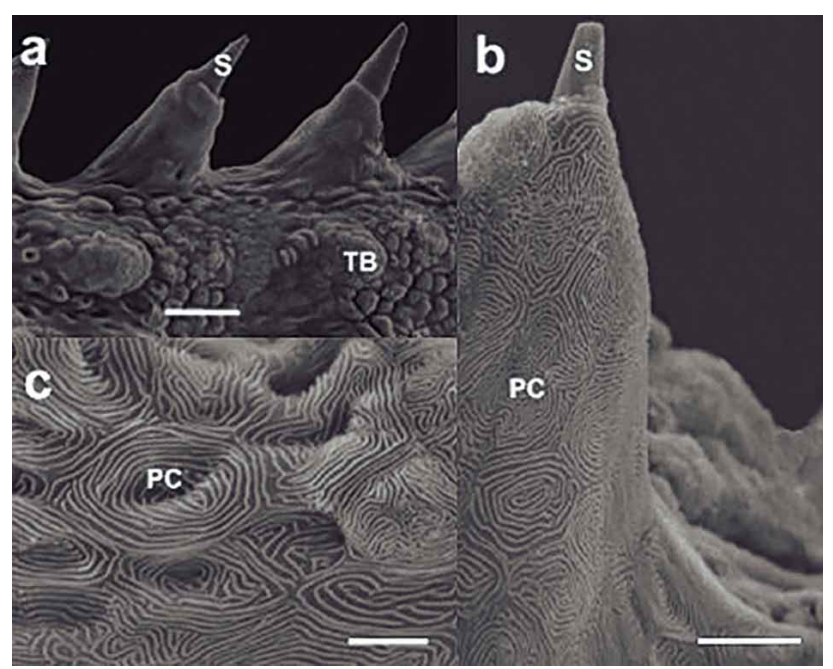

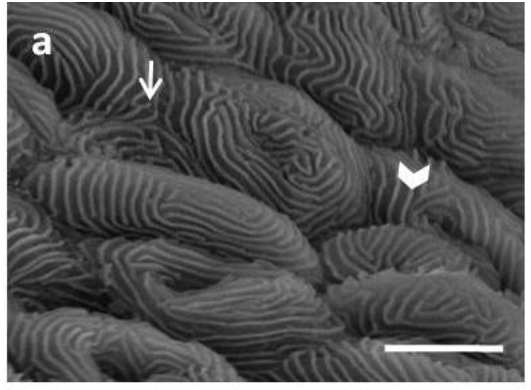

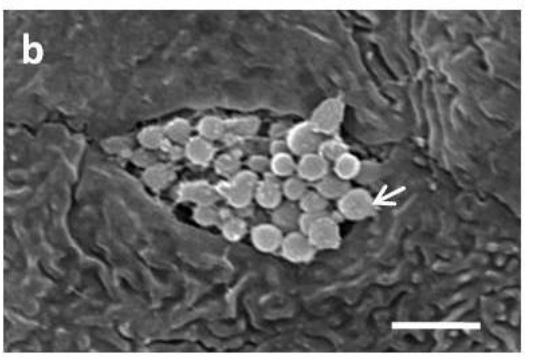

Fig. 3. (a) Surface of the stratified epithelium of primary lamellae showing the microridges (arrow head) and microbridges (arrow) of epithelial cells. Scale bar: $5 \mu \mathrm{m}$. (b) Mucous cell aperture covered by mucous globules (arrow). Scale bar: $2 \mu \mathrm{m}$ (c) Surface of the primary lamellae showing a chloride cell (arrow). Scale bar: $5 \mu \mathrm{m}$.

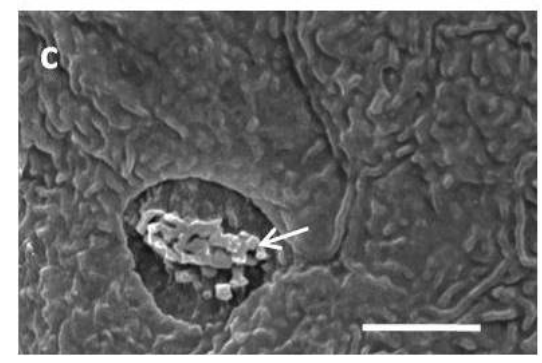

which are elongated, conical, with a single sharp-pointed end, being alike both in shape and morphology, and projecting from the epithelial surface that covers the gill rakers (Fig. 4a and b). The apical surface of the surface epithelial cells presents microridges concentrically arranged in relation to the cell boundary, thus facilitating the distinction of the individual profile of every pavement cell (Fig. 4b and c). The limits between neighboring epithelial cells are demarcated by a clearly defined wall composed of a double row of microridges. Interspersed among the epithelial cells of gill arches and gill rakers, mucous cells and prominent taste buds are observed. Type I taste buds project over the epithelial level in the apex of the epithelial protuberances. Every taste bud is located on an epithelial conical elevation (Fig. 4a and 5a). On top of each elevation, microvilli project through a taste pore (Fig. $5 b)$. Sensory protrusions of taste buds are well individualized and can be distinguished by their diameter (Fig. 5c and d); the smaller protrusions are chiefly located in the center of the taste bud, while the longest ones occupy a more peripheral position. Few Type III taste buds are seen in epithelial areas with no elevations.

Fig. 4. Scanning electron micrographs of the pharyngeal region of Odontesthes bonariensis. (a) Surface of the pharyngeal region studded with villiform spines (S) and prominent taste buds (TB). Scale bar: $25 \mu \mathrm{m}$. (b, c) Surface of the stratified epithelium of the pharyngeal region. Villiform spine (S) and pavement cells (PV). Scale bars: (b) $10 \mu \mathrm{m}$. (c) $5 \mu \mathrm{m}$. 


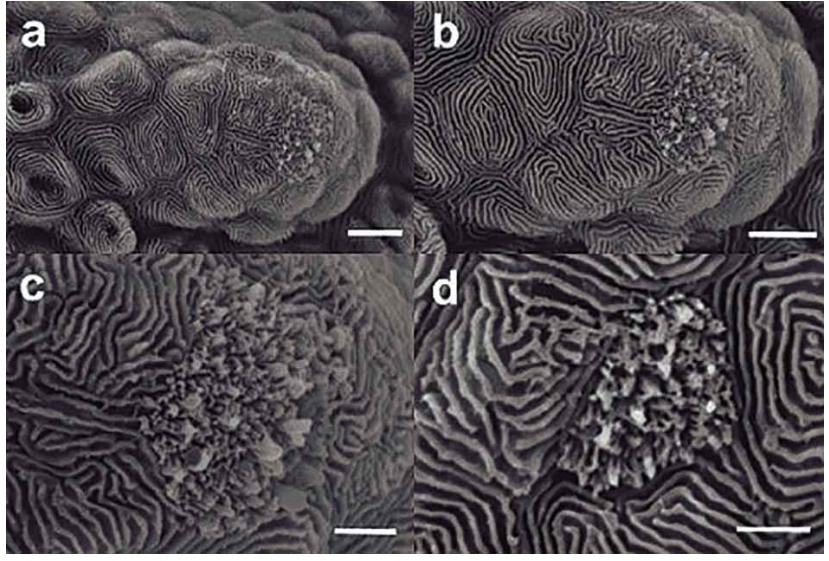

Fig. 5. (a, b) Detail of taste buds type I. Scale bars: (a) $5 \mu \mathrm{m}$. (b) 4 $\mu \mathrm{m}$. (c, d) Detail of the sensory protrusions of taste buds. Scale bars: $2 \mu \mathrm{m}$.

\section{DISCUSSION}

Gill Filaments. The general morphology of the Odontesthes bonariensis gills is similar to that found in other teleosts. The gill arches present a strong curvature in the upper third, where the filaments are shorter and similar to those located at the dorsal and ventral extremities of the BaII (Eiras-Stofella \& Charvet-Almeida, 1998; Díaz et al., 2009). The O. bonariensis gill epithelium can be subdivided in two different regions, the filament and the lamellar epithelium. The branchial filament possesses a multilayered epithelium. The superficial region of the filament epithelium mainly contains chloride and mucous cells, externally covered by pavement cells that, in addition to their role in gas exchange, are presumed to be involved in ionoregulatory mechanisms (Evans et al., 2005; Díaz et al., 2009; Monteiro et al., 2010). Lamellae, the predominant part of the arterio-arterial system, are covered by a thin epithelium. In the apical region, lamellar pavement cells form the external epithelial cover.

The most prominent feature of the pavement cells is the complex pattern of microridges that expand the area of interaction between the cell surface and the water (Díaz et al., 2009). The microridges are arranged in a concentric pattern nearly parallel to the cell borders and disseminated over the entire cell surface. Like other fish, $O$. bonariensis shows a decreasing number and size of microridges close to the secondary lamellae zone, thus indicating a transition among the different cell surface configurations (Eiras-Stofella et al., 2001; Díaz et al., 2009). In O. bonariensis, the presence of microridges in filament pavement cells and their reduction in the lamellar pavement cells may restrict the mucus accumulation in lamellae, where mucus constitutes an obstacle by favoring its accumulation in the filament surface. Further, in the filament surface, mucus can help in osmoregulatory processes by trapping water ions (Monteiro et al.).

Mucous cells have been reported in the filament epithelium of several species of teleosts. They have been also found in the secondary lamellae of some teleosts, although in smaller amounts (Díaz et al., 2005, 2010). The mucous layer that lines the surface of the pavement cells has been related to the generation of a protective water laminar flow in the interlamellar space, although it might also favor the absorption of pollutants and pathogenic agents (Monteiro et al.). As in other fish species, $O$. bonariensis presents many mucous cells in the primary lamella and in the pharyngeal region; their number significantly decreases in the secondary lamella. These morphological characteristics are probably related to gas exchange in the secondary lamellae. Thus, the thickness of the wall separating blood and oxygen in water diminishes and so does the retention of particles in the respiratory lamella, which could make difficult the gaseous, exchange (Evans et al.; Díaz et al., 2009).

Chloride cells (i.e., ionocytes, mitochondria rich cells) are thought to be a primary site of osmotic regulation in gills of euryhaline teleosts. Current morphological classification of ion transporting chloride cells is based on their surface topography, internal ultrastructure and location in the filament epithelium (Perry; Evans et al.). The most important characteristic of chloride cells from seawater fish is the presence of depressions or shallow crypts at the chloride cells' pole, and deep pits with few or no apical extensions visible. At the same time, fish inhabiting freshwater environments possess chloride cells with a wider apical surface, less evident crypts and no pits (Eiras-Stofella \& Charvet-Almeida; Perry; Eiras-Stofella et al.; Díaz et al., 2009; Itoki et al., 2012). These observations agree with the results of our study that demonstrate a low occurrence of chloride cells and slightly evident crypts.

Pharyngeal region. In most teleosts, the pharyngeal region of the branchial arches has the same shape and structural organization all along an arch and only slight morphological variations between the outer and inner sides (Eiras-Stofella \& Charvet-Almeida; Eiras-Stofella et al.). Odontesthes bonariensis shows a similar morphology at both sides of the Ball. The occurrence of short rakers with their typical spines is distinctive at both sides all along the gill arch. There is a close relation between the morphological specialization of gill rakers and the feeding habits of fish (Eiras-Stofella et al.). Fish chemosensory structures allow for food detection and selection. The short and sculptured gill rakers of $O$. bonariensis juveniles would aim at characteristics of a zooplanktophagus species. Ilyophagus species such as Mugil curema, M. liza, M. platanus and Hypostomus commersonii exhibit important 
differential features, like great development, length and elaborate sculpturing of gill rakers (Eiras-Stofella \& CharvetAlmeida; Eiras-Stofella et al.). It is probable that gills having this configuration act as a food mechanical filter instead of employing the sensory way. This hypothesis would be supported by the observation of few taste buds, spines and several mucous cells in the pharyngeal region. Hence, the presence of taste buds sending information about food would not be necessary, for the gill rakers morphology would act as a barrier to avoid the entrance of non-desirable, big sized organisms.

A typical epithelial cells surface covering different areas of the $O$. bonariensis pharyngeal region is formed by microridges of diverse and intricate patterns. The microridges are structured in different ways to form elaborate patterns and they are thought to be involved in various functions, such as absorption and secretion, increase of the surface area, trapping and holding of mucus to facilitate the adhesion of a mucous layer over the epithelial cells, and the imparting of mechanical flexibility to the free surface of epithelial cells (Vigliano et al., 2006). The microbridges, often interconnecting microridges, may be adaptations to impart firm consistency or rigidity to the surface of epithelial cells beyond the pharyngeal region of $O$. bonariensis. Kumari et al. (2005) propose that the occurrence of microbridges cooperates in protecting the epithelium of the pharyngeal zone.

The fish mucous cells are special because of their histological characteristics, size and number. In different fish species, the mucus secreted would play different functional roles in the gills (Díaz et al., 2005, 2009). Thus, mucus could be involved in the entrapment of food particles, lubrication of the epithelium, osmoregulation and absorption (Díaz et al., $2005,2009)$. The mucus produced by mucous cells lining the pharyngeal region of $O$. bonariensis may be chiefly indicative of a lubricating function which assists the smooth passage of food through the pharynx (Díaz et al. 2009).
Taste buds are greatly developed in fishes and vital for feeding, orientation and social behavior (Boudriot \& Reutter, 2001; Xiong et al., 2011). In most fishes, they are not only distributed in the oropharyngeal cavity of the mouth, but also on the basal parts of the gill arches, and they are frequently found in the skin (Fishelson et al., 2004; Xiong et al.). Taste buds are the peripheral sense organs of the gustatory system of fish as well as of other vertebrates; they allow animals to recognize food through detection of distinct chemical substances at short distances (Reutter et al., 2000). The presence of taste buds on both gill arches and rakers of $O$. bonariensis may be associated with their participation in tasting at the pharyngeal region. The morphology of most of the $O$. bonariensis pharyngeal taste buds shows that they are mostly located in the apex of elevated papillae projecting from the surface. Hence, their gross structure closely corresponds to the type I taste bud described by Reutter et al. (1974). Type III taste bud apex is level with the epithelial surface (Fishelson et al.). Moreover, Reutter et al. (1974) proposed that Type I and Type II taste buds are generally mechanoreceptors while Type III taste buds are basically chemoreceptors. The $O$. bonariensis taste buds would increase the fish efficiency for classifying and selecting food in the pharyngeal region before it reaches the esophagus. They probably differentiate the food to be ingested through mechanoreceptors and chemical receptors. Both the spines from the epithelium of the pharyngeal region and the mucus secretion would certainly help the retention of food. The presence of a large number of taste buds together with teeth suggests that food processing and gustation work simultaneously at the pharynx, and they would take part in the final determination of suitability of potential food items prior to swallowing.

\section{ACKNOWLEDGEMENTS}

We would like to thank Dr. Matilde Trivi for the English revision.

TANO DE LA HOZ, M. F.; LONGO, M. V.; ESCALANTE, A. H. \& DÍAZ, A. O. Estudio ultraestructural de las branquias de Odontesthes bonariensis (Valenciennes, 1835) (Teleostei: Atheriniformes) de un lago somero templado. Int. J. Morphol., 32(4):1341-1346, 2014.

RESUMEN: Se estudió el epitelio branquial de juveniles de Odontesthes bonariensis utilizando microscopía electrónica de barrido con un interés particular en la relación entre la morfología celular y los distintos aspectos funcionales de las branquias. Los ejemplares utilizados fueron colectados en la Laguna de los Padres, Provincia de Buenos Aires, Argentina. Los filamentos branquiales o laminillas primarias están dispuestos en dos filas a lo largo de la cara exterior convexa del arco branquial formando las hemibranquias anterior y posterior. En su cara interior cóncava, cada arco sostiene dos hileras de branquiespinas que forman la pared de la región faríngea. Las laminillas primarias están revestidas por un epitelio estratificado constituido por células poligonales con contornos bien definidos y micropliegues de la membrana celular. Se observaron numerosas células clorhídricas y mucosas en las laminillas primarias. Las células epiteliales de las laminillas secundarias tienen contornos poco definidos y escasos micropliegues. Tanto los arcos como las branquiespinas están cubiertos por un epitelio estratificado de células poligonales, entre las cuales hay abundantes células mucosas y corpúsculos gustativos. El análisis ultraestructural de las branquias de $O$. bonariensis proporciona información para avanzar en el conocimiento de la histofisiología del órgano y para realizar futuros estudios histopatológicos.

PALABRAS CLAVE: Morfología; SEM; Branquias; Peces; Odontesthes bonariensis. 


\section{REFERENCES}

Boudriot, F. \& Reutter, K. Ultrastructure of the taste buds in the blind cave fish Astyanax jordani ("Anoptichthys") and the sighted river fish Astyanax mexicanus (Teleostei, Characidae). J. Comp. Neurol., 434(4):428-44, 2001.

Carmona, R.; García-Gallego, M.; Sanz, A.; Domezaín, A. \& OstosGarrido, M. V. Chloride cells and pavement cells in gill epithelia of Acipenser naccarii: ultrastructural modifications in seawateracclimated specimens. J. Fish Biol., 64(2):553-66, 2004.

Díaz, A. O.; García, A. M. \& Goldemberg, A. L. Glycoconjugates in the branchial mucous cells of Cynoscion guatucupa (Cuvier, 1830) (Pisces: Sciaenidae). Sci. Mar., 69(4):545-53, 2005.

Díaz, A. O.; Escalante, A. H.; García, A. M. \& Goldemberg, A. L. Histology and histochemistry of the pharyngeal cavity and oesophagus of the silverside Odontesthes bonariensis (Cuvier and Valenciennes). Anat. Histol. Embryol., 35(1):42-6, 2006.

Díaz, A. O.; Castro, M. G.; García, A. M.; Díaz de Astarloa, J. M. \& Figueroa, D. E. Gross morphology and surface ultrastructure of the gills of Odontesthes argentinensis (Actinopterygii, Atherinopsidae) from a Southwestern Atlantic coastal lagoon. Tissue Cell, 41(3):193-8, 2009.

Díaz, A. O.; García, A. M.; Escalante, A. H. \& Goldemberg, A. L. Glycoproteins histochemistry of the gills of Odontesthes bonariensis (Teleostei, Atherinopsidae). J. Fish Biol., 77(7):166573, 2010.

Eiras-Stofella, D. R. \& Charvet-Almeida, P. Ultrastructure (SEM) of the gills of Prochilodus Scrofa Steindachner (Pisces, Teleostei). Rev. Bras. Zool., 15(2):279-87, 1998.

Eiras-Stofella, D. R. \& Fank-de-Carvalho, S. M. Morphology of gills of the seawater fish Cathorops spixii (Agassiz) (Ariidae) by scanning and transmission electron microscopy. Rev. Bras. Zool., 19(4):1215-20, 2002

Eiras-Stofella, D. R.; Charvet-Almeida, P.; Fanta, E. \& Vianna, A. C. Surface ultrastructure of the gills of the mullets Mugil curema, $M$. liza and M. platanus (Mugilidae, Pisces). J. Morphol., 247(2):12233, 2001.

Evans, D. H.; Piermarini, P. M. \& Choe, K. P. The multifunctional fish gill: dominant site of gas exchange, osmoregulation, acid-base regulation, and excretion of nitrogenous waste. Physiol. Rev., 85(1):97-177, 2005.

Fernandes, M. N. \& Perna-Martins, S. A. Chloride cell responses to long-term exposure to distilled and hard water in the gill of the armored catfish, Hypostomus tietensis (Loricariidae). Acta Zool., 83(4):321-8, 2002.

Fishelson, L.; Delarea, Y. \& Zverdling, A. Taste bud form and distribution on lips and in the oropharyngeal cavity of cardinal fish species (Apogonidae, Teleostei), with remarks on their dentition. J. Morphol., 259(3):316-27, 2004.
Itoki, N.; Sakamoto, T.; Hayashi, M.; Takeda, T. \& Ishimatsu, A. Morphological responses of mitochondria-rich cells to hypersaline environment in the Australian mudskipper, Periophthalmus minutus. Zool. Sci., 29(7):444-9, 2012.

Kumari, U.; Yashpal, M.; Mittal, S. \& Mittal, A. K. Morphology of the pharyngeal cavity, especially the surface ultrastructure of gill arches and gill rakers in relation to the feeding ecology of the catfish Rita rita (Siluriformes, Bagridae). J. Morphol., 265(2):197208, 2005.

Monteiro, S. M.; Oliveira, E.; Fontaínhas-Fernandes, A. \& Sousa, M. Fine structure of the branchial epithelium in the teleost Oreochromis niloticus. J. Morphol., 271(5):621-33, 2010.

Perry, S. F. The chloride cell: structure and function in the gills of freshwater fishes. Annu. Rev. Physiol., 59:325-47, 1997.

Reutter, K.; Breipohl, W. \& Bijvank, G. J. Taste bud types in fishes. II. Scanning electron microscopical investigations on Xiphophorus helleri Heckel (Poeciliidae, Cyprinodontiformes, Teleostei). Cell Tissue Res., 153(2):151-64, 1974.

Reutter, K.; Boudriot, F. \& Witt, M. Heterogeneity of fish taste bud ultrastructure as demonstrated in the holosteans Amia calva and Lepisosteusoculatus. Philos. Trans. R. Soc. Lond. B Biol. Sci., 355(1401):1225-8, 2000.

Somoza, G. M.; Miranda, L. A.; Berasain, G. E.; Colauti, D.; Remes Lenicov, M. \& Strüssmann, C. A. Historical aspects, current status and prospects of pejerrey aquaculture in South America. Aquacult. Res., 39(7):784-93, 2008.

Vigliano, F. A.; Alemañ, N.; Quiroga, M. I. \& Nieto, J. M. Ultrastructural characterization of gills in juveniles of the Argentinian Silverside, Odontesthes bonariensis (Valenciennes, 1835) (Teleostei: Atheriniformes). Anat. Histol. Embryol., 35(2):76-83, 2006.

Vigliano, F. A.; Muñoz, L.; Hernández, D.; Cerutti, P.; Bermúdez, R. \& Quiroga, M. I. An immunohistochemical study of the gut neuroendocrine system in juvenile pejerrey Odontesthes bonariensis (Valenciennes). J. Fish Biol., 78(3):901-11, 2011.

Xiong, D. M.; Zhang, L.; Ma, B. S.; Xie, C. X.; Xu, J. \& Yang, X. F. Taste buds on the external body surface and oropharyngeal cavity in Glyptosternon maculatum (Regan, 1905). J. Appl. Ichthyol., 27(4):1072-8, 2011.

\section{Correspondence to:}

Alcira Ofelia Díaz

Instituto de Investigaciones Marinas y Costeras (IIMyC)

Facultad de Ciencias Exactas y Naturales

CONICET-UNMDP

Funes $32503^{\circ}$ piso $(7600)$

Mar del Plata, Buenos Aires

ARGENTINA

Email: adiaz@mdp.edu.ar

Received: 02-07-2013

Accepted: 21-10-2014 